\title{
Prophet Mohammad's Letters From a Critical Discourse Perspective
}

\author{
Fawwaz Al-Abed Al-Haq \\ Yarmouk University, Irbid, Jordan
}

\author{
Alaa Ibraheem Qura'an \\ Taybeh Secondary School, Irbid, Jordan
}

\begin{abstract}
The aim of the present study was to determine how critical discourse analysis could be a viable approach to investigate the main persuasive strategies adopted by the Messenger, Mohammad, Prophet Mohammad peace be upon him (henceforth, PBUH), to get the rulers and governors to believe in Islam. In order to do just so, the researcher selected seven letters as the study samples. As for the findings, the study found out that the letters are very rich of persuasive strategies which vary according to the recipient himself. The study concludes that these letters are ideology-bound. The main ideology is depicted in Islamic power and superiority. In addition, considering the ruler's status and influence, the letters address rulers differently due to their status quo.

Keywords: critical discourse analysis, Messenger's letter, Islamic power and justice, discourse-as-social-practice, discourse-as-discursive practice
\end{abstract}

\section{Introduction}

\section{Theoretical Background}

Realizing that the first important step to spread Islam is through words not swords, the Messenger, Mohammad, peace be upon him (PBUH), asked all people, including his, to follow. These letters are much perceived as a peaceful and direct way to do so globally. Therefore, the letters received a great deal of attention and investigation from Islamic scholars. They have emphasized the occasions of these letters, taking into consideration some (formal) elements including the carrier, time, recipient's reaction, and final result (for further details, see Al-Hammed, 1999).

However, given the claim that these letters have been an open and wide area for research in terms of religious concepts and theories not of linguistic perspectives, the inner structure of these letters was not profoundly investigated linguistically. So, this study addresses the inner structure of these letters in terms of the main advancement of discourse analysis in general and those of critical discourse analysis in particular. The prime aim of this thesis is therefore twofold. Firstly, it examines the persuasive strategies adopted by the Messenger. Secondly, it figures out the main ideological components involved, which are frequently missed in many studies handling this significant topic. 


\section{Speech Act and Speech Act Theory}

Speech act is an act that one does when making an utterance; it is an intent utterance given due to speech principles and rule. A speech act is defined by Lyons (1977) as "an act performed in saying something" (p. 730); he claimed that the speech act is regarded as a communicative action. This means that to communicate is to express a certain attitude, and the type of speech act performed corresponds to the type of attitude being expressed. For example, an apology expresses regret; thus, a speech act does not mean the act of production of some spoken utterances, but it refers to something hidden.

Moreover, Austin (1962, p. 92) identified three distinct levels of action beyond the act of utterance itself, these include:

(1) The locutionary act which is defined as producing a sentence with its sense and reference, for example, asking or answering questions or making an appointment.

(2) The illocutionary act is defined as what a speaker intends by making it as making a statement, offer, a threat, etc., in uttering a sentence by virtue of the conversational force associated with it. For example, When are you leaving? This question can vary in its illocutionary force depending on the context. The previous question can be understood as "May I go with you?" or "Do not think it is late so it is time for you to leave".

(3) The perlocutionary act which is defined as bringing the effects on the audience by means of uttering a sentence. For example, if a jury for person declares "innocent" in a courtroom, the illocutionary act of declaring a person innocent of a crime has been undertaken. The perlocutionary act related to that illocution is that, in reasonable circumstances, the innocent would be convinced that he will be free and will not be in a jail.

The functions of language would be a kind of speech acts which is dubbed as "illocutionary acts". The Speech Act theory is a psychological linguistic theory that was introduced by Austin (1962): (1) verdictives: giving of a verdict such as appraise; (2) exercitives: involving of influence and power such as order and advice; (3) commissives: commitment of saying something such as threat; (4) behabitives: This is related to social attitudes such as apology; and (5) expositives: the state of asserting arguments such as giving reason.

Searle (1979) criticized this classification of illocutionary verbs by saying that: (1) some verbs do not satisfy the definition of the category; (2) there is no consistent principle of classification; (3) there is too much overlap of the categories and heterogeneity within the categories; and (4) there is confusion between verbs and acts.

Thus, Searle (1979) suggested five ways of using language, so he classified the illocutionary act verbs into five categories: (1) representatives: telling people how things are. For example: He asserts his competency in his job; (2) directives: attempting the speaker to get the hearer do something. For example: Close the window; (3) commissives: committing the speaker to doing something, like threatening. For example: I will kill you; (4) expressives: expressing the speaker's attitude like apologizing. For example: I am really sorry; and (5) declaratives: changing the world via the utterance. In this kind of speech, the speaker has to have a special institutional role in specific context. For example: I pronounce you the minister of education.

Discourse analysis. The term "discourse" is used in various ways within the broad field of discourse analysis. More specifically, "discourse" in an abstract sense is used as a category, designating the broadly semiotic elements (as opposed to and in relation to other, non-semiotic, elements) of social life (language, but also visual semiosis, "body language", etc.). The category of "discourse" in the social sense is defined through its relation to and difference from two other categories, "genre" and "style" (Fairclough, 1995). 
Discourse analysis is, on the whole, regarded as a relatively recent branch of linguistics, which has not been deeply examined until the second half of the last century (Brown \& Yule, 1983). Admittedly, discourse is much regarded as a broad concept with different definitions (Horvath, 2009). Titscher, Meyer, Wodak, and Vetter (2000) claimed: "Discourse integrates a whole palette of meanings, ranging from linguistics, through sociology, philosophy and other disciplines" (p. 42).

Nevertheless, van Dijk (2003) provided a more tangible definition for discourse, depicting the relationship between discourse and context. He stated that discourse is "text within context in which data are liable for empirical analysis" (p. 3). In addition, for the purposes of this study, Fairclough's definition of discourse is more recommended. He mentioned that "I shall use the term discourse to refer to the whole process of social interaction of which a text is just a part" (Fairclough, 1989, p. 24).

De Beaugrande and Dressler (1981) identified that a text is a communicative occurrence. This occurrence is depicted in seven criteria of textuality which all reflect the main strategies of discourse:

(1) Cohesion which concerns the way in which the components of the surface text, i.e., the actual words we hear or see, are mutually connected within a sequence. The surface components depend upon each other according to grammatical forms and conventions, such that cohesion rests upon grammatical dependencies.

(2) Coherence which concerns the ways in which the components of the textual word, i.e., the configuration of concepts and relations which underlie the surface text are mutually accessible and relevant. Cohesion and coherence are text-centered notions, designating operations directed at the text materials.

(3) Intentionality concerning the text producer's attitude that the set of occurrences should constitute a cohesive and coherent text instrumental in fulfilling the producer's intentions, e.g., to distribute knowledge or to attain a gale specified in a plan.

(4) Acceptability, concerning the text receiver's attitude that the set of occurrences should constitute a cohesive and coherent text having some use or relevance for the receiver, e.g., to acquire knowledge or provide co-operation in a plan.

(5) Informality which concerns the extent to which the occurrences of the presented text are expected vs. unexpected or known vs. unknown/certain.

(6) Situationality which concerns the factors which make a text relevant to as situation of occurrence.

(7) Intertextuality concerns the factors which make the utilization of one text dependent upon knowledge of one or more previously encountered texts.

Critical discourse analysis. Upon surfacing and jumping into extra-sentential levels such as text and context, one finds out that new discoursal phenomena have swiftly emerged and occupied a uniquely distinguished position among other existing linguistic phenomena (Labov \& Fanshel, 1977; Jarrah, 2012). Critical discourse analysis is an example of such a new phenomenon, which has been an open and wide area for research since then. Critical discourse analysis is first introduced into linguistics by the pioneering works of van Dijk (1993); he indicated that critical discourse analysis is clearly not a unified model, nor linguistic paradigm, but a shared point of view on doing linguistics, semiotics, or even discourse analysis.

Moreover, Batstone (1995) claimed that critical discourse analysis seeks to detect how texts are constructed. As a result, certain and potentially indoctrinating perspectives would be delicately and covertly indicated. Because these perspectives are covert, they are somehow elusive of direct challenge. 
It is hypothesized that the one element of critical discourse analysis by which it is distinguished from others, even if related, forms of discourse analysis represents in its "critical" feature. Fairclough (1992), commenting on the word "critical", stated that it is of paramount importance to expose the intended or hidden things or elements because they are not evident for the individuals involved not fought against.

Critical discourse analysis is, therefore, a kind of discourse analytical investigation which basically considers the way social power abuse, dominance, and inequality are incorporated, reproduced, and resisted by, say, the text and talk in certain contexts such as the social and political one (van Dijk, 2000). When we do critical discourse analysis, we want to understand, detect, and eventually resist social inequality. It is worth mentioning that some of the basics of critical discourse analysis can already be available in the critical theory of the Frankfurt School before the Second World War (Agger, 1992; Rasmussen, 1996).

The current focus of critical discourse analysis on language and discourse was initiated with the "critical linguistics" that emerged (mostly in the UK and Australia) at the end of the 1970s (Mey, 1985). Critical discourse analysis has also counterparts in "critical" developments in sociolinguistics, psychology, and the social sciences, some already dating back to the early 1970s (Ibanez \& Iniguez, 1997; Singh, 1996; Thomas, 1993; Turkel, 1996; Wodak, 1996).

According to van Dijk (2000), it is claimed that critical discourse analysis would be seen as a reaction against the dominant formal paradigms of the 1960s and 1970s. Critical discourse analysis is not so much a direction, school, or specialization next to the many other "approaches" in discourse studies. Rather, it aims at offering a different "mode" or "perspective" of theorizing, analysis, and application throughout the whole field. Van Dijk added that it is potential to figure out a more or less critical point of view in such different fields as pragmatics, conversation analysis, stylistics, sociolinguistics, or media analysis, among others.

Fairclough and Wodak (1997) stated that crucial for critical discourse analysts is the explicit awareness of their role in society. Continuing a tradition that rejects the possibility of a "value-free" science, they argued that science, and especially scholarly discourse, are inherently part of and influenced by social structure, and produced in social interaction. Instead of denying or ignoring such a relation between scholarship and society, they plead that such relations be investigated and accounted for in their own right, and that scholarly practices be dependent on such perspectives. Theory formation, description, and explanation are socio-politically posited whether we like it or not. Reflection is on the role of linguists in society. This may mean among other things that discourse analysts conduct research in solidarity and cooperation with dominated groups.

Flowerdew (1999), in a response to a critique by Hugh Tyrwhitt-Drake (1999) of an earlier article (Flowerdew, 1997), discussed questions of description and interpretation in critical discourse analysis. In particular, it discussed these issues under the following five postulates: Critical discourse analysis does not deal with "facts"; critical discourse analysis is reflexive; critical discourse analysis is open to multiple readings; critical discourse analysis must be plausible; and critical discourse analysis is subject to the same limitations of linguistic communication as any other discipline.

Accordingly, critical discourse analysis is a useful and thorough way to investigate and analyze the Messenger's letters sent for kings. To do so, it is imperative to consider the three stages of critical discourse analysis as determined by Fairclough (1989): (1) description stage, related to the formal properties of the text; (2) interpretation stage, concerned with the relationship between texts and interaction; and (3) explanation stage, 
concerned with the relationship between interaction and social context.

In detail, Fairclough offered his approach to the critical analysis of discourse as a good and effective method to analyze language and discourse systematically. The analysis of any text is based on three dimensions: (1) the description of the text (which he describes as discourse-as-text); (2) processing analysis which includes producing, and consuming the texts (which he describes as discourse-as-discursive practice); and (3) the larger social context or social analysis of the text which may have influenced the creation of the texts (which he describes as discourse-as-social-practice) (Waller, 2006). Figure 1 represents the three dimensions that the project follows in analyzing political speeches.

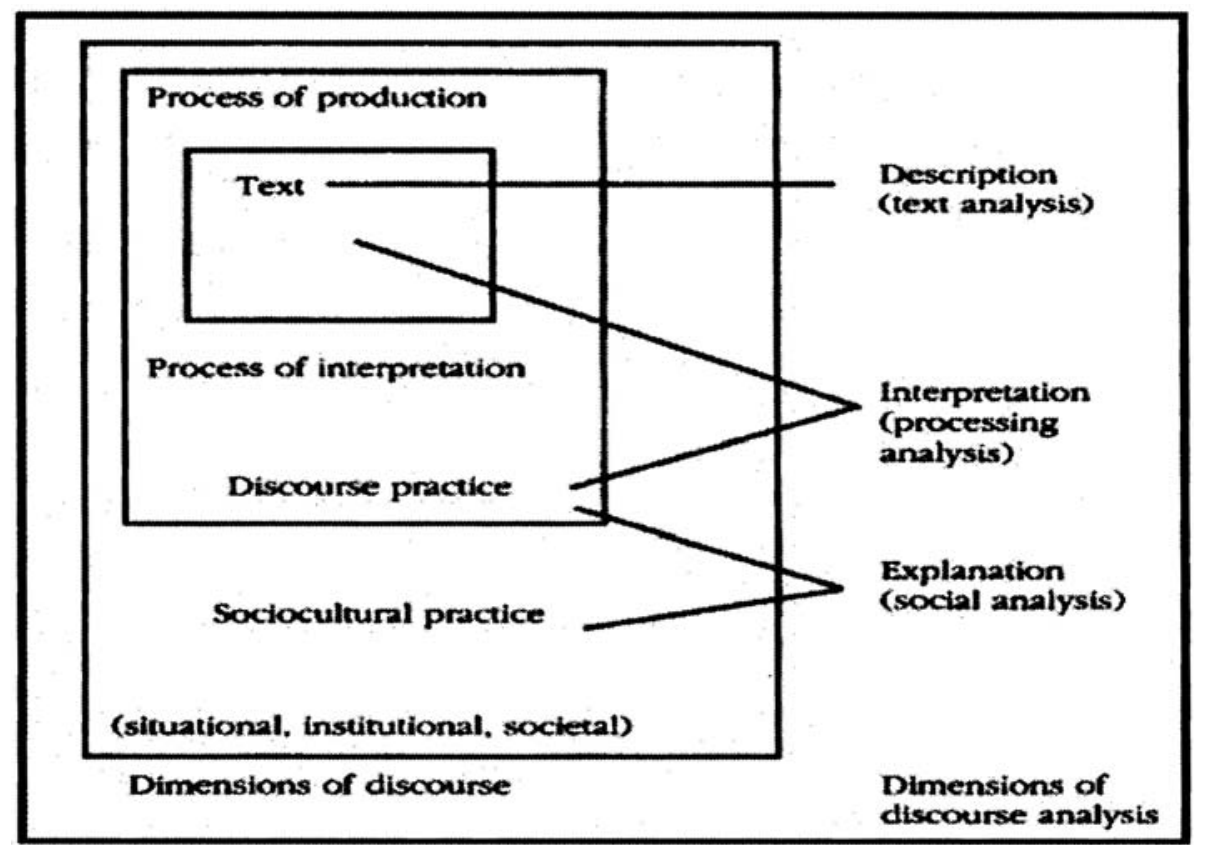

Figure 1. Fairclough's $(1989,1995)$ model for Critical Analysis of Discourse (CDA). Source: Adapted from Janks (2002, p. 27).

\section{The Formal Characteristics of Messenger's Letters}

The Messenger's letters, sent for kings, were simple in shape, appearance, and writing. They have, in reality, no decorations or extra polishing. They appear as follows:

(1) The letters were written in black ink on a soft, polished leather.

(2) They were written in a primitive or simple font, known at the time for Arabs, Al Koufi, and Al Madani.

(3) The number of words ranges between 34-107 words, as in his letter to King of Al Yamamah, which is the shortest letter in terms of number of words and 107 words as in his letter to Al-Najashee, King of Abyssinia, which is regarded as the longest letter in terms of the number of words.

(4) All of them start with Al-Basmalah, Islamic Greeting, and ended with the Messenger's seal.

(5) They were issued by naming the sender and addressee, followed by a greeting, blessing Allah Almighty, content, and (optionally) some of excerpts of the Glorious Quran, respectively (Halawani \&Taweleh, 2003).

The main concern of this thesis is to employ the three stages of critical discourse analysis as determined by Fairclough (1989) to point out the persuasive strategies, adopted by the Messenger Mohammad, PBUH, to get the kings believe in him. 


\section{Statement of the Problem}

After surveying the literature, it turned out that there were few studies which undertook the task of determining the persuasive strategies adopted by the Messenger in his letter to the kings. This paucity of research has sparked off the researcher's interest to work on this prominent subject. In general, this study's main problem is to analyze the Messengers' letters in terms of main concepts of critical discourse analysis.

\section{Purpose of the Study}

This study aims at presenting an attempt to figure out the prime mechanisms of persuasion involved in the Messenger's letters to the kings. More obviously, this work highlights the stylistic and linguistic techniques employed by the Messenger, which are evident in the letters under investigation. Therefore, the current work aims at: (1) figuring out the Messengers' letters sent to kings at the time within the main tenets of critical discourse analysis, so as to dispose how, by a two or three-lined letters, the Messenger wants to get the addressee believe in him; (2) revealing the main intended or elusive ideologies found in the letters, showing, of course, the cultural conflict and civilization inequality between the Arabs and other nations; and (3) explaining that the first and most important strategy to get other people to enter Islam is wording not fighting.

\section{Method and Procedures}

\section{Sample of the Study}

The Messenger sent 15 letters to the kings and governors of his time. The sample of the study consists of seven letters. These letters were sent to Al-Najashee, the King of Abyssinia; The Vicegerent of Egypt; Caesar, the King of Rome; The Governor of Bahrain; Chosroes, The Emperor of Persia; Harith bin Abi Shamir Al-Ghassani, King of Damascus; and Haudha bin 'Ali of Yamama. All of these letters were sent when The Messenger (PBUH) returned from Al-Hudaybiya in the sixth year of his migration to Madina Al-Munawarah. These seven letters are largely deemed the most important letters due to the addressees who were the absolute leaders of the world at the time. The most important letter is the following, taking into consideration that other letters are found in Hisham and Almalik (1995).

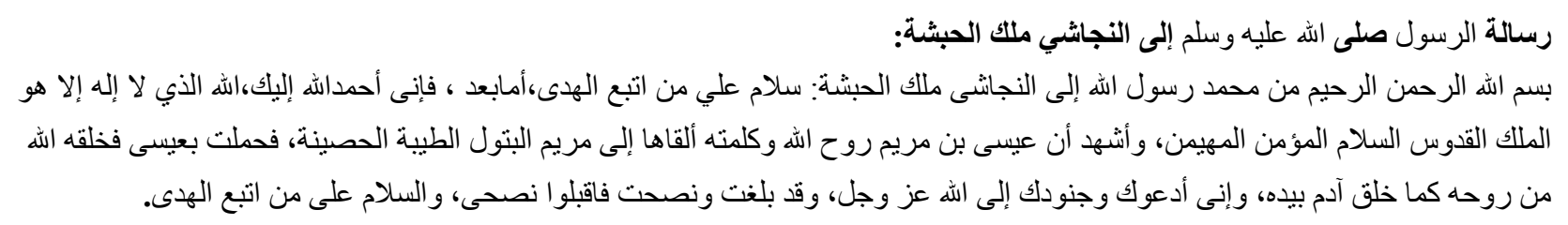
In the Name of Allah, the Most Beneficent, the Most Merciful. From Muhammad the Messenger of Allah to Negus, King of Abyssinia (Ethiopia). Peace be upon him who follows true guidance. Salutations, I entertain Allah's praise, there is no god but He, the Sovereign, the Holy, the Source of peace, the Giver of peace, the Guardian of faith, the Preserver of safety. I bear witness that Jesus, the son of Mary, is the spirit of Allah and His Word which He cast into Mary, the virgin, the good, the pure, so that she conceived Jesus. Allah created him from His spirit and His breathing as He created Adam by His Hand. I call you to Allah Alone with no associate and to His obedience and to follow me and to believe in that which came to me, for I am the Messenger of Allah. I invite you and your men to Allah, the Glorious, the All-Mighty. I hereby bear witness that I have communicated my message and advice. I invite you to listen and accept my advice. Peace be upon him who follows true guidance. 
Based on the destinations of these letters, they can be classified into two significant categories. Firstly, the domestic letters which were sent to the governors inside the Arab peninsula, whose mother tongue language is presumably Arabic. Secondly, the external letters which were sent to the rulers outside the Arab peninsula and whose mother tongue language is not Arabic. The sample of the study includes letters from both categories to get the potential findings more tangible and comprehensive. The sample of the study is clearly shown in Table 1.

Table 1

The Classifications of the Sample of the Study (the Seven Letters) Due to Destinations

\begin{tabular}{|l|l|l|l|}
\hline The domestic letters & Native language & The external letters & Native language \\
\hline The Governor of Bahrain & Arabic & The King of Abyssinia & Abyssinic \\
\hline Haudha bin 'Ali of Yamama & Arabic & The Vicegerent of Egypt & Arabic \\
\hline & & Caesar, the King of Rome & Greek \\
\hline & & Chosroes, The Emperor of Persia & Persian \\
\hline & & Harith bin Abi Shamir Al-Ghassani, King of Damascus & Arabic \\
\hline
\end{tabular}

As it is shown in Table 1, the main focus is to analyze the external letters because these letters constitute the main challenge for the Messenger to get the message of Islam. However, the remaining letters are of considerable importance, and they also deserve investigations.

\section{Data Analysis}

The conceptual basis to analyze and investigate all of these letters depends on Fairclough's perspectives and ideas on discourse. Power, discourse, and hegemony were our main focus along with the main linguistic denotations and connotations involved in these letters. Accordingly, it is likely to link the social practice and the linguistic practice as it shows in these letters. So, the macro and micro analysis of discourse as put forward by Fairclough (1989) would be our ultimate goal to reach. Besides, this thesis would analyze or deconstruct covert ideology which is hidden in these texts, gushing from the theoretical conceptualization of Batstone (1995) to reveal how these letters as a whole are constructed so that particular perspectives can be expressed delicately and covertly.

The prime analytical tool of the present thesis depicts the three-dimensional method of discourse analysis, as introduced by Fairclough (1995), namely the "language text, whether spoken or written, discourse practice, and the socio-cultural practices" (p. 57). These dimensions would be augmented throughout the thesis in a fashion which hopefully combines them totally.

\section{Review of Related Literature}

O'Halloran (2005) focused on the role of critical discourse analysis on the detection of absences from texts which mystify the social agents being described. This study depends on some data deriving from a UK newspaper website campaign to allow parents access to information about child sex offenders. O'Halloran claimed that critical discourse analysis is clear about being politically committed in its text analysis, but this commitment becomes problematic when analysts of critical discourse analysis analyze texts to evaluate how texts are potentially to mystify readers. To get such assessments sound, the researcher argued that analysts need to try to reduce the intrusion of their own subjectivity.

Taiwo (2007) conducted on three hundred Nigerian newspaper headlines which were randomly selected 
from six Nigerian newspapers and examined for peculiarity in the vocabulary and rhetorical devices used in order to identify the hidden ideologies. This study revealed that two typologies of headlines were generated, founded on the theme addressed and the surface structures. His study also revealed that hidden ideological meanings were founded in the headlines. The study also showed that these ideological meanings are obviously the opinions of the society members - served interests and undermined interests. The main conclusion showed that headlines are emotion-inducing strategy in the hands of the editor, and it also exposes that headlines are used to initiate, sustain and shape discourse on the views of readers on national issues.

Al-Omari (2009) aimed at investigating rhetoric in the Prophet's speeches from a discoursal perspective. It is based on the analysis of two khutbas by the Prophet on two significant occasions: the Greatest Fath (the Greatest Conquest of Makkah) and the Farewell khutba. The researcher adopted the procedural approach suggested by De Beaugrande and Dressler (1981) to analyze the salient features of the Prophet's rhetoric. The analysis showed how successfully the Prophet (PBUH) used the various rhetorical devices of cohesion, coherence, repetition, accuracy and simplicity, thematic organization, and syntactic forms. The main features of the Prophet's rhetoric are provided as discussed in the two khutbas. For example, direct and clear style with no vagueness or ambiguity, organized thoughts and ideas, quotations from the Holy Quran, and cohesion of the entire text.

In a more tangible critical discourse analysis study, Atawneh (2009) aimed at investigating how the language of the Israelis and the Palestinians mirrors the strengths and weaknesses of both sides. Data were gathered from the headlines reported in the local and world press at times of crises and main documented events during the second Palestinian Intifada (2001-2004). The analysis examines the types of speech acts reported in the press, determining the aggressive or defensive attitudes and focuses on Threats and Appeals together with related illocutionary verbs. The context of war and animosity will furnish the felicity conditions for the investigated speech acts. Results show that the Israelis, as the more powerful side in this conflict, use a lot of more Threats than do the Palestinians. To the contrary, a lot of more Appeals are employed by the Palestinians, which reflects, in turn, their weakness.

Horvath (2009) examined the persuasive strategies of President Obama's public speaking and the intended ideology of the same, depicted in the inaugural speeches of his. He made use of the idea "ideologies reside in texts" which was introduced by Fairclough (1995). Indeed, this study is regarded as a living manifestation of critical discourse analysis notions. The researcher came out with the conclusion that President Obama has enshrined the ideologies of pragmatism, liberalism, inclusiveness, and acceptance of religion in his speeches. Further, he claimed that the overall, underlying theme of the speech is the need to be used as a resort for rebuilding the nation in the time of global financial crisis.

Mohammad (2011) focused on explaining the most important works on the eloquence of the Prophet Mohammad both in linguistic and legislative ways. Furthermore, he explained the linguistic secrets of these works which contain eloquence and rhetoric. Indeed, he enumerated some of the types of eloquence and rhetoric of the Prophet, for example, voice bass, sign and gesture, repetition, brevity, etc.. The research explained some of the examples of the concise speech of the Messenger of Allah and explained its rhetorical aspects. The research defined the meaning of the traditions of the Prophet and their eloquence with a few examples of those traditions which demonstrate the eloquence of the Prophet in conversation and speech. 
Biria and Mohammadi (2012) investigated inaugural speeches. They claimed that the inaugural speeches as the first formal presentation of a new president play highly persuasive and ideological functions in the political scene of a country. This study shielded with a critical discourse analysis approach in order to investigate the typical discursive characteristics underlying the inaugural address. To this end, George Bush's (2005) second term and Barack Obama's (2009) first term inaugural speeches were analyzed to explore the potential ideologies signaled by the discursive strategies and rhetorical devices which these presidents employed to express their political views. The results revealed that the speakers possessed a rich repertoire of discursive mechanisms such as the positive self and negative other-presentation strategies for influencing the addressees. The findings also attested the intricate relationships existing between language, power, and ideology (For further details, see Magalhaes, 1995; Flowerdew, 1997; Morley, 2004; Chakorn, 2006; Vidali, 2009; Bhatia, 2009; Manor-Binyamini, 2011; Sowards, 2012).

\section{Findings and Discussion}

This chapter is divided into four sections. The first handles the main formal divisions of the letters. The second tackles the preliminaries of the letters. The third deals with the body of the letters which depicts the major connotations and the thrust of these letters. The fourth, in turn, examines some support or additional evidence and consolidations such as the Holy Ayah cited from the Glorious Quran which was attached under certain circumstances.

\section{Formal Divisions of the Letters}

Due to the importance of these letters, it is recommended to show the main parts of them, given that every part has its own role in delivering the messages and connotations intended. We claim that the letters do generally have a unified fashion, reflecting their definite formation. By and large, any letters consisted of three main parts: the preliminaries, the body, and the support. The first two parts seem mandatory and standardized in these letters; whereas the support is elective due to the letter circumstances and situation. After surveying the letters, it is supposed that the support is attached when the receiver is, for instance, Christian. Such a division is of paramount significance because it refers to how the Messenger (PBUH) delivers his intended messages to the addressees. Although these letters are short in terms of length and number of words, they have certain and unified parts. Each part has, in turn, an invaluable role in conveying the message. These letters are in conclusion simple but not easy.

This kind of division plays a vital part in paving the road to get the addressee understand the intended message gradually. This division is not only oriented for formal purposes but also for moral ones, given that some of these letters would be rendered to the language of the addressee. This division is also characterized by the strong affinities or linguistic bonds amongst the three parts. To be clearer, the following is one of the letters, indicating the three main parts.

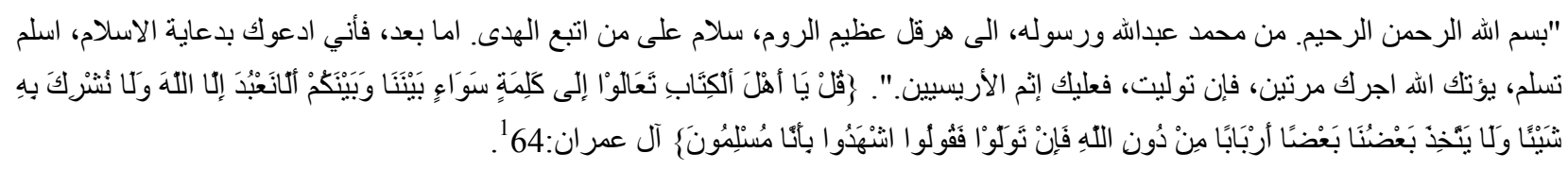

${ }^{1}$ All translations are adopted from the following site http://www.archive.org/stream/TheLettersOfProhetMuhammedpbuh/TheLettersOfTheProphetMuhammadToTheKingsBeyondAra bia_djvu.txt. 
The Letter to Caesar, the King of Rome

The Preliminaries: In the Name of Allâh, the Most Beneficent, the Most Merciful. From Muhammad, the slave of Allâh and His Messenger to Hercules, Supreme leader of the Byzantines. Blessed are those who follow true guidance.

The Body: I invite you to embrace Islam so that you may live in security. If you come within the fold of Islam, Allâh will give you double reward, but in case you turn your back upon it, then the burden of the sins of all your people shall fall on your shoulders.

The Verse: O people of the Scripture (Jews and Christians), come to a word that is just between us and you, that we worship none but Allâh, and that we associate no partners with Him, and that none of us shall take others as lords besides Allâh. Then, if they turn away, say: 'Bear witness that we are Muslims.' (The Noble Qur'an 3:64)

The first part which is here labeled as "The Preliminaries" is divided into three sub-parts: (1) Al-Basmaleh, (2) the address, and (3) the greeting.

Al-Basmaleh includes the greeting of Islam which is regarded the first and direct message, the Messenger wants to deliver. The address determines the names of the sender and receiver with a deliberate order having a great deal of significance of justice and Islamic power ${ }^{2}$. The greeting, the third sub-part, points out an additional piece of evidence in favor of calling for peace not war. The inner meanings and ideologies of these parts are the main concern of the following section. To be clearer, the following shows these three sub-parts:

$$
\text { "بسم الله الرحمن الرحيم. من محمد عبداله ورسوله، الى هرقل عظيم الروم، سلام على من اتبع الهدى". }
$$

The Preliminaries:

Al-Basmaleh: In the Name of Allâh, the Most Beneficent, the Most Merciful.

The address: From Muhammad, the slave of Allâh and His Messenger to Hercules, Supreme leader of the Byzantines.

The greeting: Blessed are those who follow true guidance.

Concerning the body, we would maintain that it is highly divided into two sub-parts: the reward and the warning. The reward is what will happen if the addressee embraces Islam. On the other hand, the warning is what will happen if he does not embrace Islam. This equation of reward and warning is regarded a new (and, of course, complete) shift in Arabic-foreign dialogue. The following represents this sub-division:

$$
\text { اما بعد، فأني أدعوك بدعاية الاسلام، اسلم تسلم، يؤتك الله اجرك مرتين، فإن نوليت، فعليك إثم الأريسيين. }
$$

The Body:

The reward: I invite you to embrace Islam so that you may live in security. If you come within the fold of Islam, Allâh will give you double reward,

The warning: but in case you turn your back upon it, then the burden of the sins of all your people shall fall on your shoulders.

\section{The Preliminaries}

As mentioned above, the preliminaries are regarded the first communication link held between the two parties. It is worth mentioning that these letters depict a highly elaborated communication. According to Wardhaugh (1986), when two or more people communicate with each other in speech or writing, this system of

${ }^{2}$ The notion of justice and power of Islam is, we believe, one of the main ideological themes intended in these letters. 
communication employs a code which has to highlight in all of its stages.

The preliminaries are characterized by being short and concise. They are the gate from which the addressee has to enter. As shown above the preliminaries part is divided into three sub-parts: al-Basmaleh, the address, and the greeting. What holds significant is their connotations. In the following, we hope to indicate how these letters were actual burden on the addressee even though the Messenger is still unknown for them all and does not stand to a real danger for them in terms of power and influence as compared with that of the addressees.

Al-Basmaleh. In general, Al-Basmaleh is a phrase which can be rendered into English as "In the Name of Allâh, the Most Beneficent, the Most Merciful". Having inserted Al-Basmaleh at the beginning of every letter sent, the Messenger applied one of the basic principles of carrying out a deed. The Messenger initiated his letters with Al-Basmaleh deliberately for other underlying purposes.

Firstly, when the letters are initiated by a set of words denoting the source of worshipping, Allah. Although Al-Basmaleh is mandatory for Muslims, it is simultaneously significant for others. The Messenger poses a mandatory status of being Muslim or, if not, be under the Islamic laws. Any upcoming potential status quo has to be within this gate, submission for Allah. Such a notion of Islamic power is highly augmented and enhanced in the body part. For instance, the notion of power is clearly apparent in the following letter:

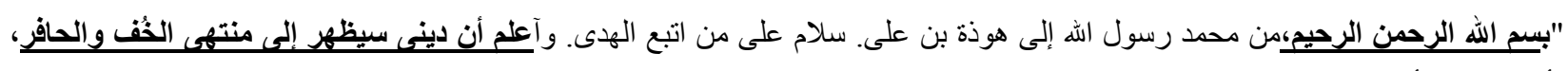

فأسلم تسلم، وأجعل للك ماتحت يديك" الرحئ

A Letter to Haudha bin 'Ali, Governor of Yamama:

"In the Name of Allâh, the Most Beneficent, the Most Merciful. From Muhammad, Messenger of Allâh to Haudhabin 'Ali. Peace be upon him who follows true guidance. Be informed that my religion shall prevail everywhere. You should accept Islam, and whatever under your command shall remain yours.”

This linkage between Al-Basmaleh and the notion of power is what Fairclough refers to as about the social context which may have influenced the creation of the text. These letters are a serious and in-depth reference to the next political stage the region would undergo. Initiated by Al-Basmaleh, the letters are meant to inform people about Islam by virtue of their leaders. This notion of Islam publicity will be one of our topics in the following parts.

Secondly, the words of "the Most Beneficent, the Most Merciful" fit much here. Admittedly, the Messenger calls leaders to convert to Islam, notifying them that Islam is based on the notions of mercy and beneficence. The Messenger does not claim positions or (as recently labeled) presidential or royal posts. In reality, this claim is largely supported by the rewarding which was mentioned in the body part. Consider this segment

$$
\text { "فأسلم تسلم، وأجعل للك ماتحت يديك" }
$$

...You should accept Islam, and whatever under your command shall remain yours.

To sum up, Al-Basmaleh reflects a set of key ideas and themes. It reflects the idea of Islamic power. The Messenger does not seek a non-conditional compromise between him and other rulers. Rather, He seeks a conditional compromise. Believes in Allah. Such a proposition of believing in Allah as a pre-condition prior any negotiations is endorsed by the "support" part which was deliberately attached when the addressee has strong religious ties, e. g., be Christian. Furthermore, it reflects the idea of "mercy and beneficence of Islam". Mentioning the characteristics of Allah as most merciful and most beneficent is significant in the context of calling to Islam. What distinguishes Islam is the social bonds found among the people themselves. The 
Messenger does claim positions but seeks to inform people about the main characteristics of Islam as a religion.

The address. Generally speaking, the address is the element which has considerable significance to all of the process of Islamic power. Due to the status quo prevalent at the time, the Arabs were the weakest circle. They totally submitted for either Romans and or the Persians. They were keen to establish good relations with the both empires dominating at the time. Admittedly, both the Romans and the Parisians used Arabs as a shield, which, in turn, reflects the devastating state of affairs the Arabians lived.

The Messenger by virtue of these letters, aimed at stating that this state of affairs is no longer existing. This declaration is much depicted in the address. Linguistically speaking, the order of interlocutors is very important and significant. The Messenger begins firstly with his name, enhanced by his role as a Messenger of Allah, prior to the name of the addressee. In all of the letters investigated, it is easy to notice this deliberate order. Actually, the Messenger mentioned himself by name, but his first name only. He does not insist on the notion of clan of tribe from which he comes. He insists that he is the Messenger of Allah.

Let us look at the address of two of these letters to highlight the notion of Islamic advent and justice.

$$
\text { من محمد عبداله ورسوله، الى هرقل عظيم الروم }
$$

The address: From Muhammad, the slave of Allâh and His Messengerto Hercules, Supreme leader of the Byzantines.

$$
\text { من محمد رسول الله إلى كسرى عظيم فارس }
$$

The address: From Muhammad, the Messenger of Allâh to Chosroes, Supreme leader of Persia.

The evidence for that is that the Messenger does not mention the clan of his or even the place where he lives. He does not attribute himself to a certain clan or place to force the addressee to think of the source of his power. In addition, the Messenger intends by this order to indicate that these letters are from a person with powers exceeding the powers of the addressees. When receiving such letters, they would promptly ask "who is Mohammad"? This invisible interaction between the interlocutors is labeled with "socio-cultural interaction" as Fairclough dubs it.

However, such power of the Messenger over other addresses does not fade the status of them away. The Messenger keeps their status available to them. He still nicknames both Hercules and Chosroes as the king or the most influential person in Byzantines and Persia, respectively.

However, the address is more and more a very paramount step towards rebuilding the Arab equality with other nations. By and large, this analysis helps us understand one of the main fundamentals of Fairclough's notions. This notion is "ideology resides in texts" and that "texts are open to diverse interpretation".

Designating all the addresses as Supreme leader or governors of their people, the Messenger wants to establish social rapport between him and the addresses. In addition, reference to the people under the control of these addresses is deemed very important for getting these letters universal, the Messenger addressed his people of all addresses when addressing the governors. Accordingly, these letters are examples of international dialogue. In fact, such a dialogue is a direct application to the task of the Messenger as being a Messenger for all people.

What is worth mentioning here is that the Messenger does not make reference in his letters to the people of addresses who are located inside the Arabian Peninsula. This can be accounted for by two integral points. Firstly, the Messenger attempts to eliminate the tribal attachment be referring to persons without their clans or tribes. Secondly, the Messenger does not mention tribes or clan by name to get, we think, all Arabians as one piece. This 
interpretation is in general compatible with one of the main principles of critical discourse analysis: "the larger social context or social analysis of the text which may have influenced the creation of the texts" (Waller, 2006).

The greeting. The greeting is the third and final part of preliminaries. Its location after the address is significant. This part is all in all short in terms of words, but it varies according to the addressee. Apparently, it is a mere greeting attached to the addressee. However, it reflects, we claim, the Messenger's understanding towards each addressee.

In detail, this part is flexible in terms of the number and nature of words. Analyzing all letters of the study sample, we can posit that the relationship between the number of words in greeting and the potential response of the addressee is significant. The Messenger is aware that each addressee will respond to the main topic of the letters differently. In addition, the ultimate goal of these letters is to get people convey the message of Islam enter Islam not to antagonize them, the Messenger adds more words to the greeting as an attempt to break the ice. Table 2 shows this significance:

Table 2

Analysis of Greeting Part of the Letters

\begin{tabular}{|c|c|c|c|}
\hline The addressee & The greeting & Arabic & $\begin{array}{l}\text { Number of } \\
\text { Arabic words }\end{array}$ \\
\hline $\begin{array}{l}\text { The King of } \\
\text { Abyssinia }\end{array}$ & Peace be upon him who follows true guidance. & سلام على من اتبع الهذى & 5 \\
\hline $\begin{array}{l}\text { The Vicegerent of } \\
\text { Egypt }\end{array}$ & Peace be upon him who follows true guidance. & سلام على من اتبع الهذى & 5 \\
\hline $\begin{array}{l}\text { Caesar, the King of } \\
\text { Rome }\end{array}$ & Peace be upon him who follows true guidance. & سلام على من اتبع الهدى & 5 \\
\hline Chosroes, The & Peace be upon him who follows true guidance, believes in & سلام على من اتبع الهدى، وآمن باله & 21 \\
\hline Emperor of Persia & $\begin{array}{l}\text { Allâh and His Messenger and testifies that there is no god } \\
\text { but Allâh Alone with no associate, and that Muhammad is } \\
\text { His slave and Messenger. }\end{array}$ & 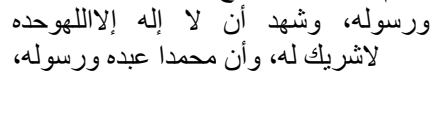 & \\
\hline $\begin{array}{l}\text { Harith bin Abi } \\
\text { Shamir Al-Ghassani, } \\
\text { King of Damascus }\end{array}$ & $\begin{array}{l}\text { Peace be upon him who follows true guidance, believes in } \\
\text { Allâh and regards it as true. }\end{array}$ & سلام على من اتبع الهـى و آمن بالة & 8 \\
\hline $\begin{array}{l}\text { The Governor of } \\
\text { Bahrain }\end{array}$ & Peace be on you. & سلامعليك & 2 \\
\hline $\begin{array}{l}\text { Haudha bin 'Ali of } \\
\text { Yamama }\end{array}$ & $\begin{array}{l}\text { Peace be upon him who follows true guidance,believes in } \\
\text { Allâh and regards it as true. }\end{array}$ & سلام على من اتبع الهدى و آمن بالله & 8 \\
\hline
\end{tabular}

Based on Table 2, we can state that the Messenger expects such call for Islam more objections from emperor of Persia, King of Damascus, and Haudha bin 'Ali of Yamama. Conversely, he expects less resistance from the remnant including the Governor of Bahrain, the emperor of Abyssinia and Rome. Such expectations are based on different factors, including: the addressee's nature himself, his position towards Arabians, and religion. Accordingly, it is possible to state that the greeting is an attempt to pave the road to get the addressee convinced of what will be mentioned in the body, the main part of the letter.

\section{The Body}

The main ideological facets depicted in these in-depth letters are best delivered in the body. These facets are apparent owing to the semantic considerations (the words used) and the syntactic ones (the structures processed). In the following we will highlight these reflections for the body of each letter, taking into consideration the significance of both sub-sections: the rewarding and warning. 
The King of Abyssinia.

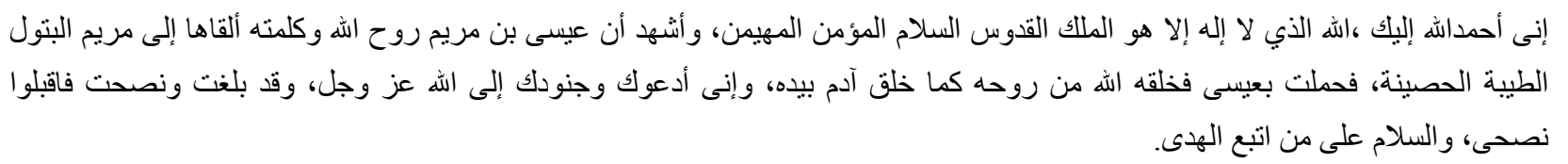
I entertain Allah's praise, there is no god but He, the Sovereign, the Holy, the peace, the Guardian of faith, the Absolute Master. I bear witness that Jesus, the son of Mary, is the spirit of Allah and His word which He cast into Mary, the virgin, the good, the pure, so that she conceived Jesus. Allah created him from His spirit and His breathing as He created Adam by His Hand. I invite you and your soldiers to Allah, the Glorious, the Almighty. I hereby bear witness that I have communicated my message and advice. I invite you to listen and accept my advice. Peace be upon him who follows true guidance.

This letter entails how the Messenger utilizes the common social context to get the recipient believe in what he calls for. Actually, it is really an interesting application of what is called as "discourse-as-discursive practice". In detail, the Messenger produces the body in a way proving that he is a real Messenger. As known, the main purpose of real Christianity is worshipping Allah, the principle which is extremely clear in this section of the body. In reality, the Sovereign, the Holy, the peace, the Guardian of faith, and the Absolute Master are some of the Allah's prominent features, denoting that the source of Islam is Allah.

At a more developing level of mutuality, the Messenger mentions very critical state of affairs of Jesus, the most significant figure in Christianity. The Messenger mentions who Jesus is, who Mary is, what the relationship between Jesus and Adam is like, and how he is conceived. As stated earlier, the Messenger does not look for political positions or merits; he seeks for spreading Islam across the world. As a result, it can be stated that these messages are really considered effective tools to ask people for Islam.

Further, the emphasis on the idea of the king and his people is also a magnificent example of what is called as "discourse-as-social-practice". In fact, this practice is much rendered as the larger social context or social analysis of the text which may have influenced the creation of the texts. Addressing the kings is a good chance to address his people as well. Specifically, the Messenger calls the people of Abyssinia as the soldiers of the king. In reality, such a label helps the Messenger to convey his gratitude to this king. Moreover, the idea of soldiers is much derived from the Christianity teachings which claim that the people are all soldiers under the command of the king, who plays a role of Jesus representative. In fact, this shows how the Messenger respects other religions teachings and tenets. Consequently, this depiction of Jesus representative determines that the source of information of the letter is not human sources but Allah's one.

What holds significant here is the idea of absence of both the rewarding and warning in this letter in comparison with other letters. This can be solved if the social practice is directly linked with the discourse practice. As it is widely known, the rewarding and warning are found already in the Christianity teachings and principles. As both Islam and Christianity are derived from heaven sources, they have basically the same articles of faith. The Messenger provides some pieces of evidence, validating that he is really one of Allah's Messenger. Therefore, he keeps the rewarding and warning not mentioned because the King of Abyssinia, a real Christian, is fully familiar with.

This also provides hard-evidence that the Messenger is aware, in turn, with the main teachings of Christianity. Table 3 summarizes the sentences their functions. 
Table 3

Sentences and Function in the Letter Sent to the King of Abyssinia

\begin{tabular}{|c|c|c|}
\hline No. & Sentence & Function \\
\hline 1 & I entertain Allah's praise & Attracting attention \\
\hline 2 & $\begin{array}{l}\text { there is no god but He, the Sovereign, the Holy, the peace, the Guardian of faith, the Absolute } \\
\text { Master }\end{array}$ & Evidence \\
\hline 3 & $\begin{array}{l}\text { I bear witness that Jesus, the son of Mary, is the spirit of Allah and His word which He cast into } \\
\text { Mary, the virgin, the good, the pure, so that she conceived Jesus }\end{array}$ & Evidence \\
\hline 4 & Allah created him from His spirit and His breathing as He created Adam by His Hand & Evidence \\
\hline 5 & I invite you and your soldiers to Allah, the Glorious, the Almighty & The call \\
\hline 6 & I invite you to listen and accept my advice & Specifying the call \\
\hline 7 & Peace be upon him who follows true guidance & The conclusion \\
\hline
\end{tabular}

\section{Hercules the Vicegerent of Egypt.}

$$
\text { "فإني أدعوك بدعوة الإسلام، أسلم تسلم يؤتكاللهأجرك مرتين فإن أبيت،فإن عليك إثم أهل القبط". }
$$

Thereafter, I invite you to accept Islam. Therefore, if you want security, accept Islam. If you accept Islam, Allah, the Sublime, shall reward you doubly. But if you refuse to do so, responsibility for the transgression of the entire nation shall be yours.

Despite the fact that the Vicegerent of Egypt is a Christian like the King of Abyssina, the body of the former's letter is partially different from the latter. In detail, in the current letter, there are no sentences aiming to attract the recipient's attention. The Messenger initiates the body of the current letter through calling the Vicegerent to accept the message of Islam directly.

It seems that this Vicegerent does not need tools to get him attracted to the topic. On the other hand, it can be stated that providing further pieces of evidence about Allah and Jesus does not matter because the Vicegerent of Egypt is more oriented for political grounds not religious goals. Put differently, what holds important for the Vicegerent is never the religion but the political positions or influence.

Besides, the Vicegerent of Egypt was well known for his loyalty to the Roman Empire. This means that he is not free to take decision on his own. Accordingly, the best way to get him believe in Islam is the rewarding and warning techniques. The prudent reading and investigation of the current letter body points out that it consists of imperative and declarative sentences (see Table 4).

Table 4

Sentences and Function in the Letter Sent to the Vicegerent of Egypt

\begin{tabular}{llll}
\hline No. & Sentence & Type & Function \\
\hline 1 & I invite you to accept Islam & Declarative & The call \\
2 & if you want security, accept Islam & Imperative & The rewarding \\
3 & If you accept Islam, Allah, the Sublime, shall reward you doubly & Declarative & Maximizing the rewarding \\
4 & $\begin{array}{l}\text { But if you refuse to do so, responsibility for the transgression of the } \\
\text { entire nation shall be yours }\end{array}$ & Declarative & Warning \\
\hline
\end{tabular}

\section{The Governor of Bahrain.}

"فإني أحمد الله إليك الذي لا إله غبره و أنثهد أن لا إله إلا الله وأن محمدأعبده ورسوله أما بعد فإني أذكرك الله عز وجل فإنه من ينصح فإنما ينصح

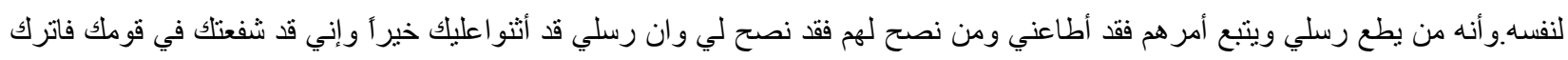
للمسلمين ما أسلموا لله وعفوت عن أهل الذنوب فأقبل منهم و إنك مهما تصلح فلن نعزلك عن عن عملك ومن ومن أقام على دينه وسنته فعليه الجزية". 
I entertain Allah's praise, there is no god but He, and I bear witness that Muhammad is His slave and Messenger. Thereafter, I remind you of Allah, the Mighty, and the Glorious. Whoever accepts admonition, does it for his own good. Whoever follows my Messengers and acts in accordance with their guidance, he, in fact, accepts my advice. My Messengers have highly praised your behavior. You shall continue in your present office. Give the new Muslims full chance to preach their religion. I accept your recommendation regarding the people of Bahrain, and I pardon the offences of the offenders; therefore, you may also forgive them. Of the people of Bahrain whoever wants to go on in their faith, should be made to pay Jizya.

The Messenger initiates his letter of reminding the ruler with Allah, Almighty. On the whole, this ruler has previous knowledge of Allah, Almighty; this knowledge is a good reason to begin with. As stated earlier, the Messenger does not seek for political benefits but for spreading Islam of which Allah, Almighty is the core.

What holds important here to mention is why this letter including more could accept the call; accordingly, the next step is to organize the people themselves. This letter actually tackles the problem which may surge when the ruler declares his Islam. He is not ordered to kill those who decline the call but to enforce them to pay Al-Jizya. In fact, all of these instructions state implicitly that Islam is the fate of all people in these regions; the existence of laws and instructions entail that everything was planned and the people now is the period of application of Islam to all peoples not only this ruler's ones. The word "my Messengers" indicates the prophet sends Messengers to all people and tribes. So, we can claim that this mention of the word Messengers is a kind of apprehension. Table 5 shows all sentences of the current letter body and functions.

Table 5

Sentences and Function in the Letter Sent to the Governor of Bahrain

\begin{tabular}{|c|c|c|}
\hline No. & Sentence & Function \\
\hline 1 & I entertain Allah's praise & Attracting attention \\
\hline 2 & there is no god but He, the Sovereign, the Holy, the peace, the Guardian of faith, the Absolute Master & Evidence \\
\hline 3 & I remind you of Allah, the Mighty, and the Glorious & The common belief \\
\hline 4 & Whoever accepts admonition, does it for his own good & Attraction \\
\hline 5 & $\begin{array}{l}\text { Whoever follows my Messengers and acts in accordance with their guidance, he, in fact, accepts my } \\
\text { advice }\end{array}$ & Apprehension \\
\hline 6 & My Messengers have highly praised your behavior & Praising \\
\hline 7 & You shall continue in your present office & Rewarding \\
\hline 8 & Give the new Muslims full chance to preach their religion & Instructions \\
\hline 9 & $\begin{array}{l}\text { I accept your recommendation regarding the people of Bahrainand I pardon the offences of the } \\
\text { offenders }\end{array}$ & Rewarding \\
\hline 10 & therefore, you may also forgive them & Instructions \\
\hline 11 & Of the people of Bahrain whoever wants to go on in their faith,should be made to pay Jizya. & Instructions \\
\hline
\end{tabular}

As indicated in Table 5, the Messenger uses the strategies of apprehension, attraction, rewarding, and orders to get the ruler of Bahrain to accept the call of Islam.

Chosroes, the Emperor of Persia.

"أدعوك بدعاية الله، فإني أنا رسول الله إلى الناس كافة، لينذر من كان حيا ويحق القول على الكافرين فأسلم تسلم، فإن أبيت فإن إثم المجوس عليك".

I invite you to accept the religion of Allah. I am the Messenger of Allah sent to all people in order that I may infuse fear of Allah in every living person, and that the charge may be proved against those who reject the Truth. 
Accept Islam as our religion so that you may live in security, otherwise, you will be responsible for all the sins of the Magians.

The Messenger initiates the body of the current letter through calling the Chosroes, the Emperor of Persia to accept the message of Islam. In addition, the Messenger provides this ruler with the information that he is the Messenger of Allah. Indeed, this information is of paramount important hence the Chosroes, the Emperor of Persia does not have any mutual or presupposed knowledge of the Messenger of Allah. Besides, the Messenger explains both the rewarding and warming which may happen when this ruler accepts the call or declines it. Again, the idea of people is present in this letter. Table 6 shows all sentences of the current letter with their functions.

Table 6

Sentences and Function in the Letter Sent to Chosroes, the Emperor of Persia

\begin{tabular}{|c|c|c|}
\hline No. & Sentence & Function \\
\hline 1 & I invite you to accept the religion of Allah & The call \\
\hline 2 & $\begin{array}{l}\text { I am the Messenger of Allah sent to all people in order that I may infuse fear of Allah in every } \\
\text { living person, and that the charge may be proved against those who reject the Truth }\end{array}$ & Familiarity information \\
\hline 3 & Accept Islam as our religion so that you may live in security & Rewarding \\
\hline 4 & otherwise, you will be responsible for all the sins of the Magians. & Warning \\
\hline
\end{tabular}

Harith bin Abi Shamir Al-Ghassani, King of Damascus.

"و إنى ادعوك إلى أن تؤمن بالهه وحده لا شريك له. ييقي للك ملكك".

I invite you to believe in Allah Alone with no associate, thence after your kingdom will remain yours.

This letter provides us with another example of how each letter fits its recipient. What matters for the Messenger at this time is to get people believe in Allah. Therefore, The Messenger does not mention any extra information. As indicated, this letter lacks the warning and includes only two short sentences, indicating the call and rewarding for accepting it as shown in Table 7 below:

Table 7

Sentences and Function in the Letter Sent to Harith bin Abi Shamir Al-Ghassani, King of Damascus

\begin{tabular}{lll}
\hline No. & Sentence & Function \\
\hline 1 & I invite you to believe in Allah Alone with no associate & The call \\
2 & thence after your kingdom will remain yours & Rewarding \\
\hline
\end{tabular}

All in all, the shortness of this letter provides us with essential clues to decipher one of the ideological components of the letters. On the whole, the Messenger draws a balance between the probability of this ruler to accept Islam and the letter length. As this ruler is expected to decline the call, mentioning rewarding apart from warning is enough to maximize this probability. This significant relationship explains the level of interpretation as posited by Fairclough. The interpretation level which is concerned with the relationship between text and interaction is very clear in this letter. In detail, the absence of warning is a kind of interpretative act. The Messenger is there to call people for Islam, not to fight them. As a result, mentioning the warning is not accepted to change the status quo.

\section{Haudha bin 'Ali of Yamama.}

$$
\text { "و آعلم أن دينى سيظهر إلى منتهى الخُف والحافر ، فأسلم تسلم، وأجعل للك ماتحت يديك". }
$$

Be informed that my religion shall prevail everywhere. You should accept Islam, and whatever under your 
command shall remain yours.

It can be stated that this letter along with the letter sent to the Ruler of Bahrain initiated by the warning and then rewarding in comparison with the letters sent to other rulers who live outside the Arab peninsula, whose letters are initiated by rewarding not warming.

Actually the sentence "Be informed that my religion shall prevail everywhere" is a kind of implicit warning. The rewarding comes next with the sentences "You should accept Islam, and whatever under your command shall remain yours", as shown in Table 8.

Table 8

Sentences and Function in the Letter Sent to Haudha bin 'Ali of Yamama

\begin{tabular}{lll}
\hline No. & Sentence & Function \\
\hline 1 & Be informed that my religion shall prevail everywhere & Warning \\
2 & You should accept Islam & Rewarding \\
3 & and whatever under your command shall remain yours & Extra rewarding \\
\hline
\end{tabular}

Caesar, the King of Rome.

"فإنى أدعوك بدعوة الإسلام أسلم تسلميؤتكاللهأجرك مرتين، فإن توليت فعليك إثم جميع الآريسيّين". I invite you to embrace Islam so that you may live in security. If you come within the fold of Islam, Allah will give you double reward, but in case you turn your back upon it, then the burden of the sins of all your people shall fall on your shoulders.

The letter of the current letter consists of three sentences: the first the call, the second the rewarding, and the third the warning as mentioned in Table 9.

Table 9

Sentences and Function in the Letter Sent to Caesar, the King of Rome

\begin{tabular}{lll}
\hline No. & Sentence & Function \\
\hline 1 & I invite you to embrace Islam so that you may live in security & Call \\
2 & If you come within the fold of Islam, Allah will give you double reward & Rewarding \\
3 & but in case you turn your back upon it, then the burden of the sins of all your & Warning \\
& people shall fall on your shoulders. & \\
\hline
\end{tabular}

\section{Support}

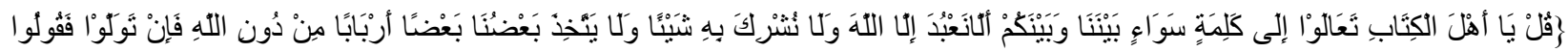

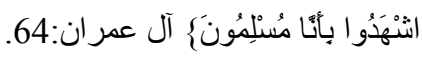

O people of the Book! leaving aside all matters of difference and dispute, agree on a matter which is equally consistent between you and us and it is that we should not worship anyone except Allah and that we should neither associate anyone with Him, nor make anyone else as our God.

This section consists mainly of a Holy Ayah cited form the Glorious Quran. This verse summarizes the main points and aspects of the Messenger's call. More specifically, the most important thing is the belief in Allah, this section is not attached to letter only when the recipient is Christian. Yet, it can be stated that if the Messenger, PBUH, sends letters to Jewish leaders, this section may be present. Linguistically speaking, the prime aim of this section is to provide hard-evidence for the Messenger' honesty as a real Messenger of Allah.

Moreover, this section is not attached to the King of Abyssinia's letter although that he is a Christian. The 
reason for that can be accounted for by the belief that the Messenger proves his honestyas a real Messenger of Allah via taking on Jesus the Christ.

\section{Conclusions and Recommendations}

\section{Conclusions}

The current study comes up with the following conclusions: (1) The study concludes that these letters are direct applications of the relationship between the discourse and the social practice in which the discourse is created; (2) these letters are full of persuasive strategies adopted by the Messenger in order to convey the message of Islam; (3) these letters are ideology bound. The main ideology of all letters is to enforce evolving Islamic power or justice; (4) the letters consider the ruler's status and influence in that they address the rulers differently; (5) all parts of the letters serve the goals of they were intended to induce; (6) all letters have fixed order and exact sections; (7) length of letters is significant and refers to the Messenger's presuppositions towards the rulers and governors; and (8) it can be supposed that the domestic letters are different from the external ones with order of warning and rewarding.

\section{Recommendations}

Having studied the letters in terms of the main principles of critical discourse analysis, the researcher recommends the following for further research: (1) investigating other Messenger letters. Many studies dealing with such letters and speeches emphasize their layouts and religious underlying roles without indicating how the Messenger persuades other rulers; (2) drawing a comparison between the Messenger's, PBUH, letters and the replying letters from the rulers and governors, proving the difference in between; (3) undertaking a study to indicate whether these strategies adopted by the Messenger are adapted from the Glorious Quran or not; and (4) investigating these letters from a different point of view such as the Relevance Theory, hope to find out other mechanism the Messenger adopts to deliver Islam.

\section{References}

Adetunji, A. (2007). Perspectives on media discourse (pp. 40-60). Munchen: Lincom Europa.

Agger, B. (1992). The discourse of domination. From the Frankfurt school to postmodernism. Evanston, IL: Northwestern University Press.

Ahmed, M. (2011). رسائل الرسول :المنهج الديني في التبليغ (The prophet’s letters: The religious method in spreading Islam). Damascus: Dar Alqalam.

Al-Hammed, M. (1999). Political discourse analysis: An Arabic English contrastive cause study (Unpublished MA thesis). Yarmouk University, Irbid, Jordan.

Al-Omari, S. (2009). Fearuers of rhetoric on the prophet's speech (Unpublished MA thesis). YarmoukUniversity, Irbid, Jordan. Atawneh, A. M. (2009). The discourse of war in the Middle East: Analysis of media reporting. Journal of Pragmatics, 41, $263-278$. Austin, J. (1962). How to do things with words. Cambridge: Cambridge University Press.

Batstone, R. (1995). Grammar in discourse: Attitude and deniability. In G. Cook \& B. Seidlhofer (Eds.), Principle \& practice in applied linguistics (pp. 197-213). Oxford: Oxford University Press.

Bhatia, A. (2009). The discourses of terrorism. Journal of Pragmatics, 41(2), 279-289.

Biria, R., \& Mohammadi, A. (2012). The socio pragmatic functions of inaugural speech: A critical discourse analysis approach. Journal of Pragmatics, 44(10), 1290-1302.

Brown, G., \& Yule, G. (1983). Discourse analysis. Cambridge: Cambridge University Press.

Campbell, C. P. (1998). Rhetorical ethos: A bridge between high-context and low-context cultures. In S. Niemeier, C. P. Campbell, \& R. Dirven (Eds.), The cultural context in business communication. Amsterdam/Philadelphia: John Benjamins. 
Chakorn, O. (2006). Persuasive and politeness strategies in cross-cultural letters of request in the Thai business context. Journal of Asian Pacific Communication, Special Issue on Asian Business Discourse, 16(1), 103-146.

De Beaugrande, B., \& Dressler, W. (1981). Introduction to the study of text and discourse. London: Longman.

Fairclough, N. (1989). Language and power. London: Longman.

Fairclough, N. (1992). Discourse and social change. London: Polity Press.

Fairclough, N. (1995). Critical discourse analysis: The critical study of language. Harlow, UK: Longman.

Fairclough, N., \& Wodak, R. (1997). Critical discourse analysis. In T. A. van Dijk (Ed.), Discourse studies: A multidisciplinary introduction (Vol. 2, pp. 258-84). London: Sage.

Flowerdew, J. (1997). The discourse of colonial withdrawal: A case study in the creation of mythic discourse. Discourse and Society, $8(4), 493-571$.

Flowerdew, J. (1999). Writing for scholarly publication in English: The case of Hong Kong. Journal of Second Language Writing, 8(2), 123-145.

Halawani, M., \& Taweleh, A. A. (2003). عالمية الاسلام و رسائل النبي- صلى اله علية وسلم - الى الملوك والأمر اء (Universality of Islam and the prophet's letters-Peace be upon him—To the kings and princes). Damascus: Dar al qalam.

Hinds, J. (1990). Inductive, deductive, quasi-inductive: Expository writing in Japanese, Korean, Chinese, and Thai. In U. M. Connor \& A. Johns (Eds.), Coherence in writing: Research and pedagogical perspectives (pp. 87-109). Alexandria, VA: TESOL.

Hisham, I., \& Almalik, A. (1995). سيرة النبي - صلى الله عليه وسلم (Biography of the prophet-Peace be upon him). Tanta: Dar al sahabah Lil torath.

Horvath, J. (2009). Critical discourse analysis of Obama's political discourse. In M. Ferenčík \& J. Horváth (Eds.), Language, literature and culture in a changing transatlantic world (pp. 45-56). Presov: University of Presov.

Ibanez, T., \& Iniguez, L. (Eds). (1997). Critical social psychology. London: Sage.

Janks, H. (2002). Critical discourse analysis as a research tool. In M. Toolan (Ed.), Critical discourse analysis (Vol. 4, pp. 26-42). London: Routledge.

Jarrah, M. (2012). The functions of concessive discourse analysis: A relevance-theoretical approach (Unpublished MA thesis). Yarmouk University, Irbid, Jordan.

Kafori, M., \& Aldeen, S. (1976). الرحيق المختوم (Al raheek Almakhtoom). Beirut: Dar Ihya Altorath Alarabi.

Kaplan, R. B. (1966). Cultural thought patterns in intercultural education. Language Learning, 16, 1-20.

Labov, W., \& Fanshel, D. (1977). Therapeutic discourse. New York: Academic Press.

Lyons, J. (1977). Semantics. Cambridge: Cambridge University Press.

Magalhães, M. (1995). A critical discourse analysis of gender relations in Brazil. Journal of Pragmatics, 23, 183-197.

Manor-Binyamini, I. (2011). A model of ethnographic discourse analysis for an interdisciplinary team. Journal of Pragmatics, 43(7), 1997-2011.

Mey, J. L. (1985). Whose language: A study in linguistic pragmatics. Amsterdam: Benjamins.

Morley, J. (2004). Power and ideology in everyday discourse: The relevance of critical discourse analysis in pragmatic linguistics today. Retrieved from http://library.sakura.juntendo.ac.jp/bunken/kiyou/vol8/20.pdf

O'Halloran, K. (2005). Causal cognition and socio-cognition in critical discourse analysis: A reply to Rick Iedema. Linguistics and Education, 16, 338-348.

Rasmussen, D. M. (Ed.). (1996). The handbook of critical theory. Oxford: Blackwell.

Searle, J. (1979). Expression and Meaning. Cambridge: Cambridge University Press.

Searle, J. (1980). Speech Act theory and pragmatics. Dordrecht: Reidel.

Siderits, M., Johannsen, W., \& Fadden, T. (1985). Gender, role, and power: Content analysis of speech. Psychology of Women Quarterly, 9, 439-450.

Singh, R. (Ed.). (1996). Towards a critical sociolinguistics. Amsterdam: Benjamins.

Sowards, K. (2012). Rhetorical functions of letter writing: Dialogic collaboration, affirmation, and catharsis in Dolores Huerta's letters. Communication Quarterly, 60(2), 295-315.

Taiwo, R. (2007). Language, ideology and power relations in Nigerian newspaper headlines. In R. Taiwo, A. Odebunmi, \& A. Adetunji (Eds.), Perspectives on media discourse. Germany, München: LINCOM Europa.

Thomas, J. (1993). Doing critical ethnography. Newbury Park: Sage.

Titscher, S., Meyer, M., Wodak, R., \& Vetter, E. (2000). Methods of text and discourse analysis. London: Sage.

Turkel, G. (1996). Law and society. Critical approaches. Boston, MA: Allyn and Bacon.

Van Dijk, T. A. (1993). Principles of critical discourse analysis. Discourse and Society, 4(2), 249-283. 
Van Dijk, T. A. (2000). Parliamentary debates. In R. Dins Wodak \& van Dijk, T. A. (Eds.), Racism at the top. Parliamentary discourses on ethnic issues in six European states (pp. 45-78). Klagenfurt, Austria: Drava Verlag.

Van Dijk, T. A. (2003). Critical discourse analysis. In D. Schiffrin, D. Tannen, \& H. E. Hamilton (Eds.), The handbook of discourse analysis (pp. 352-371). Oxford: Blackwell.

Vidali, A. (2009). Rhetorical hiccups: Disability disclosure in letters of recommendation. University of Colorado Denver. Rhetoric Review, 28(2), 185-204.

Waller, L. (2006). Introducing Fairclough's critical discourse analysis methodology for analyzing caribbean social problems: Going beyond systems, resources, social action, social practices and forces of structure or lack thereof as units of analysis. Journal of Diplomatic Language, 3(1), 12.

Wardhaugh, R. (1986). An introduction to sociolinguistics (p. 384). New York: Blackwell.

Wodak, R. (1996). Disorders of discourse. London: Longman. 